\title{
Physical and hydraulic properties of soils under a long-term tillage practices in Hadejia Local Government Area, Jigawa State, Nigeria
}

\author{
Abba Nabayi *, Abubakar Halilu Girei, Mohammed Saleh Abubakar
}

Department of Soil Science, Faculty of Agriculture, Federal University Dutse, Jigawa State, Nigeria

\section{Article Info}

Received : 09.11.2018

Accepted : 24.05.2019

\begin{abstract}
The study was conducted to determine the effects of different tillage practices on some physical and hydraulic properties of soils in Hadejia Local Government Area of Jigawa state during the 2017 cropping season. The field experiment was laid in a Randomized Complete Block (RCB) Design in factorial arrangements with 4 treatments for tillage practices-TP (Zero tillage-ZT, Minimum tillage-MT, Conventional tillage-CT and Deep tillage-DT) and sampling depth-SD $(5 \mathrm{~cm}, 15 \mathrm{~cm}, 25 \mathrm{~cm}$ and $35 \mathrm{~cm})$ all were in four replicates. Data collected were analyzed using the generalized linear model of Statistical Analyses System (SAS 9.4) for the ANOVA. The results showed that there were significant differences $(p<0.05)$ in the main effect of TP and SD as well as in the interaction effect between TP and SD on soil bulk density (Bd), saturated hydraulic conductivity (Ksat), volumetric moisture content (VWC) at different soil water potentials and plant available water (PAW). Greater $\mathrm{Bd}$ and Ksat were observed in DT which differed significantly $(\mathrm{p}<0.05)$ from other TP while the lowest was found in ZT with $6.5 \%$ reduction than DT. The result further showed no significant difference in terms of PAW ( $p>0.05)$ between the TP at the average depth of 15 and $25 \mathrm{~cm}$, but they (TP) differed significantly at the average depth of 5 and $35 \mathrm{~cm}$ with the highest in ZT. Higher soil moisture content retained at all soil water pressure was found in ZT which differed significantly $(\mathrm{p}<0.01)$ form other TP. The research concluded that the best TP to be adopted in Hadejia in terms of improvement in physical and hydraulic properties is ZT practice.
\end{abstract}

Keywords: Conventional tillage, deep tillage, minimum tillage, sampling depth, tillage practices, zero tillage

(c) 2019 Federation of Eurasian Soil Science Societies. All rights reserved

\section{Introduction}

Tillage is the mechanical disturbance of the soil for the purpose of crop production. Over the decades, focus has been drawn to the effects of different tillage practices on some physical and hydraulic properties of soils around the globe. However, increasing demand for food and fiber by the ever-growing human population has placed high stress on farmers to produce large quantity of food to meet this demand. One of the means to increase the output is through the employment of modern Agricultural machineries like ploughs, harrows, planters, harvesters etc. These machineries lead to high output per unit area, timely and efficient operations and reduction of drudgery associated with crop production. These practices, however, have shown to be highly destructive of the soil, which resulted to about $24 \%$ of the global agricultural land degradation (Bai et al., 2008).

Irrigation management practices largely depend on accurate and timely characterization of spatial and temporal soil moisture changes in the root zone, especially in arid and semi-arid regions. Conservation

\footnotetext{
${ }^{*}$ Corresponding author.

Department of Soil Science, Faculty of Agriculture, Federal University Dutse, Jigawa State, Nigeria

Tel.: +2347031068906

E-mail address: abba.nabayi@fud.edu.ng e-ISSN: $2147-4249$ DOI: $10.18393 /$ ejss.573914
} 
tillage has increasingly been utilized as the agricultural best management practice to reduce soil erosion (Salem et al., 2015). The knowledge outcome of conservation tillage on soil moisture conditions, soil compaction and soil temperature, has become a major concern among producers considering adopting this tillage system (Licht and Al-Kaisi, 2005). Soil compaction is usually determined by measuring soil bulk density and cone index. Soil bulk density and cone index are also utilized to predict the depth of soil hardpans (Mehari et al., 2005; Afzalinia and Zabihi, 2014). Therefore, evaluating the effects of conservation tillage practices on soil moisture and compaction can help to explain some of the differences in plant growth and development under different tillage practices (Licht and Al-Kaisi, 2005).

Undesirable management practices cause degradation in soil health; depletion of organic matter and other nutrients, as well as decline in crop productivity (Ramos et al., 2011). Reducing disturbance of soil by reduced tillage influences several physically (López-Garrido et al., 2012), chemically (Page et al., 1986), and biologically (Bronick and Lal, 2005; Muñoz et al., 2007) interconnected properties of the natural body. Soil tillage is one of the important factors influencing soil properties and crop yield. Among the crop production factors, tillage contributes up to 20\% (Khurshid et al., 2006) and affects the sustainable use of soil resources through its influence on soil properties (Lal and Stewart, 2013). Therefore, currently there is a significant interest and emphasis on the shift from extreme tillage to conservation and or no-tillage methods for the purpose of controlling erosion process and preserving soil nutrients (Iqbal et al., 2005). Conventional tillage practices cause change in soil structure by modifying soil bulk density and soil moisture content. In addition, repeated disturbance by conventional tillage produces a finer and loose-setting soil structure while conservation and no-tillage methods leave the soil intact (Rashidi and Keshavarzpour, 2007). The number, size, and distribution of pores again control the ability of soil to store and transmit water, air and agricultural chemicals and, thus, in turn, regulate erosion, runoff, and crop performance (Khan et al., 2001).

Generally, these properties are affected by land management practices associated with row crop and perennial crop production practices (Zaibon et al., 2016). A research conducted by Fuentes et al. (2004) by comparing the hydraulic properties under natural prairie, conventional tillage, and no-till management for silt loam soils (Ultic Haploxerolls), discovered that in the natural prairie, hydraulic conductivity values were about one order of magnitude larger than in the cultivated soils. They concluded that even after 27 years of continuous no-till, hydraulic properties were not restored to the original values of the prairie soils.

However, scientific researches are limited on the effect of tillage practices on the rainfed arable land in the Hadejia area. The research has been initiated to determine the best tillage practices with desirable soil properties. The soil physical and hydraulic properties investigated include bulk density, soil water retention, saturated hydraulic conductivity and pore size distribution. This research was carried out to evaluate the effect of tillage practices on bulk density, saturated hydraulic conductivity and water retention of the dryland soil under the four (4) different tillage practices. We hypothesized that differences in tillage practices would have significant effects on the physical and hydraulic properties of the soils.

\section{Material and Methods}

\section{Experimental site}

The study was conducted at four different locations (Lat. $12.46^{\circ} 06^{1} \mathrm{~N}$ and Long.10.04 $08^{\circ} \mathrm{E}$, Lat. $12.46^{\circ} 01^{1} \mathrm{~N}$ and Long.10.04 $09^{1} \mathrm{E}$, Lat. $12.47^{\circ} 03^{1} \mathrm{~N}$ and Long. $10.04^{\circ} 07^{1} \mathrm{E}$ and Lat.12.46 $04^{1} \mathrm{~N}$ and Long.10.040 $03^{1} \mathrm{E}$ ) in Hadejia local govt. area. The ecological zone is Sudan savannah which comprises of scattered trees and sparse vegetation. Rainfall ranges from 500-700 mm annually and rains between the month of June and October, mean annual temperature ranges from $27^{\circ} \mathrm{C}$ to $38^{\circ} \mathrm{C}$. The experimental sites were continuously being utilised for rainfed cultivation of cereals and legumes for a long period of time.

\section{Experimental design and treatments}

The Tillage Practices (TP) were considered as first factor and the sampling depth (SD) as the second factor, with four (4) replications each which were laid in Randomized Complete Block design in a factorial arrangement. The four tillage practices were; Zero tillage (ZT: no any tillage activity is performed), Minimum tillage (MT: using hoe manually), Conventional tillage (CT: ox-ploughed by animal to a depth of about $15 \mathrm{~cm}$ ) and Deep tillage (DT: tillage by chisel plough up to $22-25 \mathrm{~cm}$ depth using a tractor). The sampling depths included; 0-10 cm (average $=5 \mathrm{~cm}$ ), $10-20 \mathrm{~cm}$ (average $=15 \mathrm{~cm}$ ), 20-30 cm (average $=25 \mathrm{~cm}$ ) and $30-40 \mathrm{~cm}$ (average $=35 \mathrm{~cm}$ ). 


\section{Soil sampling and analysis}

Undisturbed soil samples were taken using aluminum ring core samplers at the sites in the month of October 2017. The core samplers had a dimension of $5 \times 5 \mathrm{~cm}$ each. The samples were collected by $10 \mathrm{~cm}$ increment from 0 to $40 \mathrm{~cm}$ depth for each tillage practice, making a total of 64 soil core samples. The sample cores were trimmed, covered the top and bottom openings, labelled and sealed in plastic bags and transported to the laboratory for measurements and analyses.

\section{Particle size analysis}

Particle size analysis was conducted using Bouyoucos hydrometer method, where sodium hexametaphosphate (Calgon) was used as a dispersant agent (Gee and Bauder, 1986). The USDA textural triangle was used to determine the textural class of the soil samples.

\section{Bulk density (Bd) and soil moisture contents (MC)}

Bulk density was determined using core method (Blake and Hartge, 1986). The soil was taken by pressing the core ring and carefully removed to preserve a known volume. Sample was then oven dried to $105^{\circ} \mathrm{C}$ for 24 hours and reweighed to determine the oven dry weight. The bulk density and moisture content were calculated thus;

$$
\begin{aligned}
& \text { Bulk Density }\left(\mathrm{Mg} \mathrm{m}^{-3}\right)=\frac{\text { Weight of ovendried soil sample at } 105^{\circ} \mathrm{C}}{\text { Total Volume of fresh soil sample }} \\
& \text { Moisture Content }\left(\mathrm{g} \mathrm{g}^{-1}\right)=\frac{\text { Weight fresh soil sample }- \text { Weight of ovendried soil sample }}{\text { Weight of ovendried soil sample }} \times 100
\end{aligned}
$$

\section{Saturated hydraulic conductivity (Ksat)}

The saturated hydraulic conductivity of the soil samples was determined by constant head method as described by Klute and Dirksen (1986). To determine the hydraulic conductivity, calibrated measuring cylinder was placed on the stand and followed by funnel on top of the cylinder, then a brass ring covered one side with white cloth and tighten with rubber ring was placed in the funnel and the required amount of the soil sample was placed inside the brass ring. Volumetric flask with the required amount of water was tilted upside down by the help of clamp and then the water was released by removing the stopper of volumetric flask to the brass ring with already contained soil sample, then the water drops into the measuring cylinder. The quantity of dropped water has been measured as well as the time taken. Hydraulic conductivity was calculated using the formula below;

$$
\text { Ksat }\left(\mathrm{cm} \mathrm{hr}^{-1}\right)=\frac{\mathrm{QL}}{\mathrm{ATH}}
$$

where Ksat is the saturated hydraulic conductivity $(\mathrm{cm} / \mathrm{h}), \mathrm{Q}$ is the volume of water collected $\left(\mathrm{cm}^{3}\right), T$ is the time taken (hr), A is the cross-sectional area of the sample $\left(\mathrm{cm}^{2}\right), \mathrm{H}$ is the hydraulic head difference $(\mathrm{cm})$, and $\mathrm{L}$ is the length of the soil column $(\mathrm{cm})$

\section{Soil water retention}

Water retention of the soils under different tillage practices at different sampling depth was determined using the pressure plate and pressure membrane described by Richards (1947). The soil of a known weight was put into the core ring and placed on porous ceramic plates and was placed inside a pressure chamber for 7 days. The applied pressure was $0.1,1,10,33$, and $1500 \mathrm{kPa}$. The samples were then oven dried at 105 ${ }^{\circ} \mathrm{C}$ for 24 hours which was weighed and multiply by the soil bulk density to obtain the volumetric moisture content (VMC).

\section{Data analysis}

Minitab 16, was used to test the normality for the parameters studied, which was conducted using Anderson-Darling at $P=0.05$. All data collected were analyzed using Statistical Analyses System (SAS 9.4 SAS system for windows by SAS Institute Inc., Cary, NC, USA). Analysis of Variance (ANOVA) and Proc GLM were used to determine the significant treatment effect on the measured properties with the significant difference of $p<0.05$. Least significant difference (LSD) was used for mean separation to detect significant difference between the means. 


\section{Results and Discussion}

The results of main and interactive effects of various tillage practices and sampling depth on bulk density (Bd) and saturated hydraulic conductivity were presented in Table 2 . The results showed significant effect of tillage practices and sampling depth as well as their interaction on soil $B d(p<0.05)$. The mean values of the bulk densities differed significantly from one tillage practice to another in the order DT $>$ CT $>$ MT $>$ ZT with DT having 3.3\%, 5.2\% and 6.5\% higher bulk densities than CT, MT and ZT respectively. Similar result was reported by Alam et al. (2014) who also recorded highest bulk density reduction $(6.41 \%)$ in ZT followed by MT (3.95\%). Higher Bd obtained in DT could be due to soil compaction attributed to regular machinery used for ploughing. The lower Bd observed in ZT may be attributed to the maximum utilization of the soil vegetative cover year-in year-out. Many researchers (Rachman et al., 2004; Liebig et al., 2005; Mudgal et al., 2010) acknowledged the influence of vegetative cover on soil bulk density; the higher the vegetative cover the lower the bulk density of a soil. The sampling depth also differed from one another statistically $(\mathrm{P}<0.05)$ in terms of Bd. Higher bulk density values were recorded in the lower depth whereas the lowest Bd values were obtained in the upper depths. There was 1.4\% increment in Bd in the lower depth $(20-40 \mathrm{~cm})$ over the upper depth $(0-20 \mathrm{~cm})$. the Lower Bd values in the upper depth was due to the organic residues that are being left behind after harvest which decomposes and translocated up to some certain levels of the soil profile. The results agree with Seobi et al. (2005) who reported concomitant increase in Bd with an increase in sampling depth. The interaction effect between tillage practices and soil depth on Bd is presented in Figure 1a. The interaction showed that the Bd values increases with increase in depth in virtually all the tillage practices, with the exception of ZT which remain constant at the average depth of 5,15 and $25 \mathrm{~cm}$ depth and then increases with $2.7 \%$ at the lower average depth of $35 \mathrm{~cm}$. Bd of CT also remain unstable throughout the different sampling depth, which increases and decreases alternately as the depth progressed.

Table 2. Analysis of variance (ANOVA) and main effect means for bulk density and saturated hydraulic conductivity. Main effects are Tillage practices and sampling depth.

\begin{tabular}{|c|c|c|}
\hline & \multicolumn{2}{|c|}{ ANOVA $P>F$} \\
\hline Source of Variation & Bulk Density (Bd) & Sat. Hydraulic Conductivity (SHC) \\
\hline Replication (R) & 0.1573 & 0.0596 \\
\hline Tillage practices $(\mathrm{T})$ & $<0.0001$ & $<0.0001$ \\
\hline $\mathrm{T}^{*} \mathrm{R}$ & 0.0493 & 0.2274 \\
\hline Sampling depth (D) & $<0.0001$ & $<0.0001$ \\
\hline $\mathrm{T}^{*} \mathrm{D}$ & $<0.0001$ & $<0.0001$ \\
\hline Tillage practices & \multicolumn{2}{|r|}{ Means } \\
\hline ZT & $1.43 \mathrm{~d}$ & $0.75 \mathrm{~d}$ \\
\hline MT & $1.45 c$ & $1.84 \mathrm{~b}$ \\
\hline $\mathrm{CT}$ & $1.48 \mathrm{~b}$ & $1.02 \mathrm{c}$ \\
\hline DT & $1.53 \mathrm{a}$ & $2.90 \mathrm{a}$ \\
\hline LSD & 0.02 & 0.14 \\
\hline \multicolumn{3}{|l|}{ Sampling depth (cm) } \\
\hline $0-10 \mathrm{~cm}$ & $1.46 \mathrm{~b}$ & $1.76 \mathrm{~b}$ \\
\hline $10-20 \mathrm{~cm}$ & $1.46 \mathrm{~b}$ & $1.41 \mathrm{c}$ \\
\hline $20-30 \mathrm{~cm}$ & $1.48 \mathrm{a}$ & $1.43 c$ \\
\hline $30-40 \mathrm{~cm}$ & $1.49 \mathrm{a}$ & $1.91 \mathrm{a}$ \\
\hline LSD & 0.02 & 0.14 \\
\hline
\end{tabular}

Mean comparisons were made only when $P$ values for the main effects were $\leq 0.05$. Means followed by same letters within the same column (for a given $\mathrm{Bd}$ and SHC) are not significantly different from one another at $5 \%$ level of significance.

The result presented in Table 2 and Figure $1 \mathrm{~b}$ showed significant difference $(\mathrm{P}<0.05)$ in the main effect of tillage practices, sampling depth and the interaction of the two on saturated hydraulic conductivity (Ksat). The highest Ksat was recorded under DT which differed significantly from that of other tillage practices in the order of DT $>$ MT $>$ CT $>$ ZT with DT having an increment of $36.5 \%, 64.8 \%$ and $74 \%$ over MT, CT and ZT respectively. Despite having wide margin in Ksat values between the tillage practices, ZT, CT and MT all fall under the saturated hydraulic conductivity class of moderately slow (Teh and Jamal, 2006), with only DT having different class of moderate among the tillage practices. However, in terms of the sampling depth, Ksat differed from one another but they all fall under moderate slow class. Particle size distribution plays a vital role in determining the saturated hydraulic conductivity of soils. Higher Ksat in DT was due to the 
proportion of sand, silt and clay content of the soil under tillage practice possessed. DT had higher proportion of sand and lower percentage of clay across the sampling depths (Table 1) when compared with the soils under other TP, and sandy soils had very rapid conductivity of water than silt and clay soils. The results of Ksat disagrees with Seobi et al. (2005) and Mudgal et al. (2010) but concurred with Zaibon et al. (2016) who indicated that normally, Ksat decreases with sampling depth due to the overburden pressure of the overlying soil, the downward movement of fine particles, and fewer roots, which reduce the proportion of interconnected pores and the pore size distribution. Seobi et al. (2005) reported that Ksat at 0-10 cm soil depth was 36 times greater than at the $30-40 \mathrm{~cm}$ soil depth. They found that the lowest value of Ksat at the 30-40 cm soil depth was due to the higher concentration of smectite clay in that soil horizon (Seobi et al., 2005), however, in this study it was found contrary because of higher proportion of sand content as shown in Table 1.

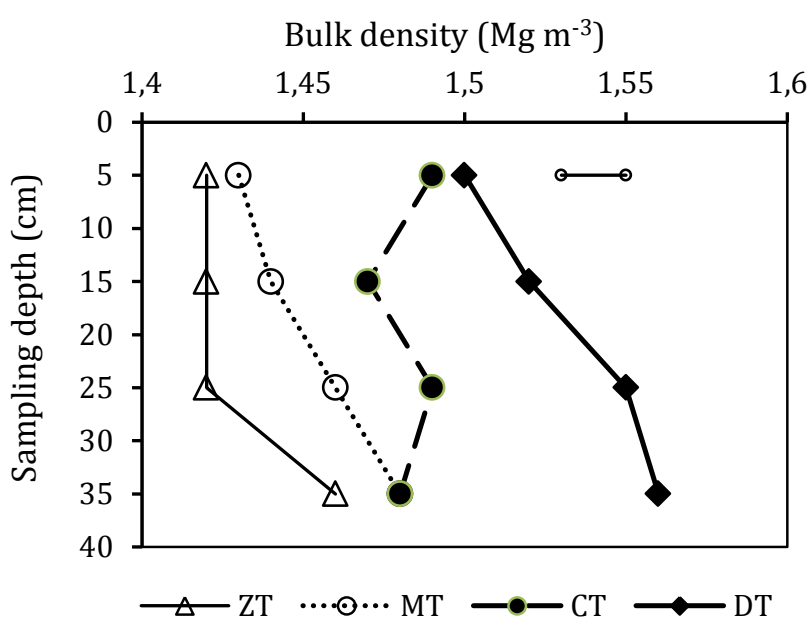

(a)

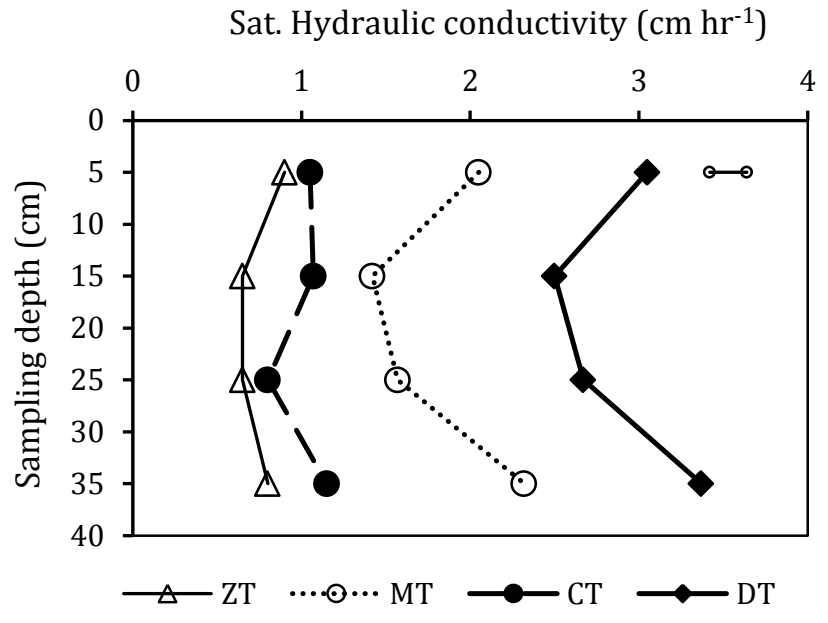

(b)

Figure 1. Effect of (a) Tillage practices and sampling depth on Bulk density (Bd) and (b) Tillage practices and sampling depth on saturated hydraulic conductivity (SHC). Bars indicate LSD values at $5 \%$ level of significance.

ZT: Zero tillage, MT: Minimum tillage, CT: Conventional tillage, DT: Deep tillage

The interaction effect between TP and SD (Figure $1 \mathrm{~b}$ ) on Ksat followed the same trend for all the tillage practices. They all decrease from $5 \mathrm{~cm}$ average depth to $15 \mathrm{~cm}$ and then increases slightly at $25 \mathrm{~cm}$ and finally increases considerably at the final average sampling depth $(35 \mathrm{~cm})$ greater than the initial sampling depth. Higher Ksat values observed at the $5 \mathrm{~cm}$ depth compared to 15 and $25 \mathrm{~cm}$ was due to the greater percentage of organic matter content at the surfaces and lower clay content than at the deeper depth (Table $1)$, while at the same time significant Ksat values at the deeper depth $(35 \mathrm{~cm})$ than its upper depths counterparts was because of the significant proportion of the sand content in the depth.

Table 1. Particle size analyses of the experimental soils under different tillage practices at different sampling depth.

\begin{tabular}{|c|c|c|c|c|c|}
\hline Tillage practices & Sampling depth $(\mathrm{cm})$ & Clay (\%) & Silt (\%) & Sand (\%) & Textural class \\
\hline \multirow[t]{4}{*}{ ZT } & $0-10$ & 12 & 19 & 69 & Sandy loam \\
\hline & $10-20$ & 12 & 22 & 66 & Sandy loam \\
\hline & $20-30$ & 13 & 22 & 65 & Sandy loam \\
\hline & $30-40$ & 14 & 22 & 64 & Sandy loam \\
\hline \multirow[t]{4}{*}{ MT } & $0-10$ & 14 & 19 & 67 & Sandy loam \\
\hline & $10-20$ & 14 & 19 & 66 & Sandy loam \\
\hline & $20-30$ & 15 & 21 & 64 & Sandy loam \\
\hline & $30-40$ & 16 & 21 & 63 & Sandy loam \\
\hline \multirow[t]{4}{*}{ CT } & $0-10$ & 22 & 14 & 64 & Sandy clay loam \\
\hline & $10-20$ & 23 & 15 & 62 & Sandy clay loam \\
\hline & $20-30$ & 22 & 16 & 62 & Sandy clay loam \\
\hline & $30-40$ & 23 & 17 & 60 & Sandy clay loam \\
\hline \multirow[t]{4}{*}{ DT } & $0-10$ & 16 & 13 & 71 & Sandy loam \\
\hline & $10-20$ & 17 & 13 & 70 & Sandy loam \\
\hline & $20-30$ & 16 & 14 & 70 & Sandy loam \\
\hline & $30-40$ & 18 & 14 & 68 & Sandy loam \\
\hline
\end{tabular}

ZT: Zero tillage, MT: Minimum tillage, CT: Conventional tillage, DT: Deep tillage 
The ANOVA results for soil water retention (Table 3) showed that tillage practices had a significant effect $(\mathrm{P}<$ 0.05 ) on volumetric moisture content retained at all soil water pressures. The result showed that ZT had higher moisture content at all the soil water pressures than other tillage practices. This result suggests that conservation tillage practices and soil management can affect soil water retention at all soil water pressure range. Consequently, this range of soil water pressure is affected by soil structure and root distribution effects. Soil water retention differed significantly with sampling depth $(\mathrm{P}<0.05)$, and the interactions between TP and SD were also significant $(\mathrm{P}<0.05)$ which is presented in Figure 2. Volumetric moisture contents (VMC) in the ZT practice was significantly different from all TP at all soil water pressure except at $0.1 \mathrm{kpa}$ which indicated no significant difference among all the TP (Figure 2a). Similar trend was observed in Figure 2c but it did not differ significantly from CT. At 15 and $35 \mathrm{~cm}$ depth (Figure 2b and 2d), similar trend was observed with ZT having higher moisture content which differed significantly $(\mathrm{P}<0.05)$ from other TP at 1, 33 and $1500 \mathrm{kpa}$ only while DT had the lowest moisture content at these soil water pressure. Soil water retention is also a function of soil structure; total porosity and aggregates distribution. Allowing land under ZT to be covered with residues and vegetation during raining season is an important activity towards aggregate stability and increasing soil pore spaces which added a greater below ground biomass as compared with other tillage practices. Bulk density results were numerically lower at virtually all the depth for the ZT practice, which perhaps contributed to higher water retained in the ZT practice. Root of crops and weeds also played a significant role towards having lower Bd values and greater water retention of the soil under ZT practice. Mudgal et al. (2010) reported that because of the shallowest topsoil in the upper depth (4 $\mathrm{cm})$, it had more water content than deeper depth.

Table 3. Analysis of variance (ANOVA) and main effect means for volumetric moisture content (VMC) across a range of soil water pressures. Main effects are Tillage practices and sampling depth

\begin{tabular}{llccrr}
\hline \multicolumn{7}{c}{ ANOVA P>F } & & & \\
\hline Source of Variation & $\mathbf{0 . 1 k p a}$ & 1kpa & 10kpa & 33kpa & 1500kpa \\
\hline Replication (R) & 0.5925 & 0.9116 & 0.4200 & 0.4362 & 0.1253 \\
Tillage practices (T) & 0.0277 & $<0.0001$ & 0.0002 & $<0.0001$ & $<0.0001$ \\
T*R & 0.7313 & 0.8398 & 0.3332 & 0.1255 & 0.9693 \\
Sampling depth (D) & 0.5823 & 0.1588 & 0.0102 & $<0.0001$ & $<0.0001$ \\
T*D & 0.0304 & 0.0003 & 0.0006 & $<0.0001$ & $<0.0001$ \\
Tillage practices & & VMC $\left(\mathrm{m}^{3} \mathrm{~m}^{-3}\right)$ & Means & & \\
ZT & $0.450 \mathrm{a}$ & $0.394 \mathrm{a}$ & $0.354 \mathrm{a}$ & $0.316 \mathrm{a}$ & $0.185 \mathrm{a}$ \\
MT & $0.440 \mathrm{~b}$ & $0.368 \mathrm{~b}$ & $0.342 \mathrm{~b}$ & $0.254 \mathrm{c}$ & $0.144 \mathrm{c}$ \\
CT & $0.450 \mathrm{a}$ & $0.375 \mathrm{~b}$ & $0.342 \mathrm{~b}$ & $0.290 \mathrm{~b}$ & $0.164 \mathrm{~b}$ \\
DT & $0.445 \mathrm{ab}$ & $0.373 \mathrm{~b}$ & $0.336 \mathrm{~b}$ & $0.223 \mathrm{~d}$ & $0.106 \mathrm{~d}$ \\
LSD & 0.006 & 0.008 & 0.007 & 0.006 & 0.006 \\
Sampling depth(cm) & & & & & \\
$0-10 \mathrm{~cm}$ & $0.452 \mathrm{a}$ & $0.381 \mathrm{a}$ & $0.347 \mathrm{a}$ & $0.267 \mathrm{~b}$ & $0.146 \mathrm{~b}$ \\
$10-20 \mathrm{~cm}$ & $0.446 \mathrm{ab}$ & $0.378 \mathrm{ab}$ & $0.347 \mathrm{a}$ & $0.278 \mathrm{a}$ & $0.156 \mathrm{a}$ \\
$20-30 \mathrm{~cm}$ & $0.451 \mathrm{a}$ & $0.379 \mathrm{ab}$ & $0.343 \mathrm{ab}$ & $0.279 \mathrm{a}$ & $0.159 \mathrm{a}$ \\
$30-40 \mathrm{~cm}$ & $0.445 \mathrm{ab}$ & $0.372 \mathrm{~b}$ & $0.336 \mathrm{~b}$ & $0.255 \mathrm{c}$ & $0.137 \mathrm{c}$ \\
LSD & 0.006 & 0.008 & 0.007 & 0.006 & 0.006 \\
\hline
\end{tabular}

Mean comparisons were made only when $P$ values for the main effects were $\leq 0.05$. Means followed by same letters within the same column (for a given soil water pressure) are not significantly different from one another at $5 \%$ level of significance.

Figure 2 indicated that water content of a soil under different tillage practices can be different at all the soil water pressure levels. In terms of plant available water $(\mathrm{FC}-\mathrm{PWP})$, significant difference $(\mathrm{P}<0.05)$ was observed only at 5 and $35 \mathrm{~cm}$ average depth. However, at $5 \mathrm{~cm}$ depth the PAW was recorded in the order of ZT $>$ CT $>$ DT $>$ MT with ZT having an increase of 31.5\%, 42.1\% and 47.3\% over CT, DT and MT respectively. At the deeper/lower depth, the increase in PAW followed this order ZT $>$ CT $>$ MT $>$ DT with $7.8 \%$ and $15.4 \%$ each of MT and DT. MT and DT had similar PAW at the lower depth $(35 \mathrm{~cm})$. The result disagrees with Alam et al. (2014) who found the maximum Available water content under DT, then followed by ZT, even though, it was after 2 cropping cycles. 


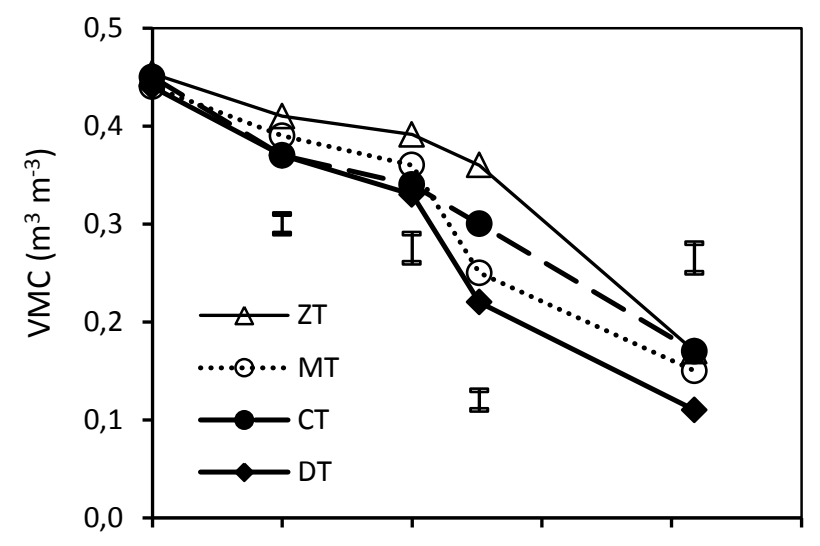

(a)

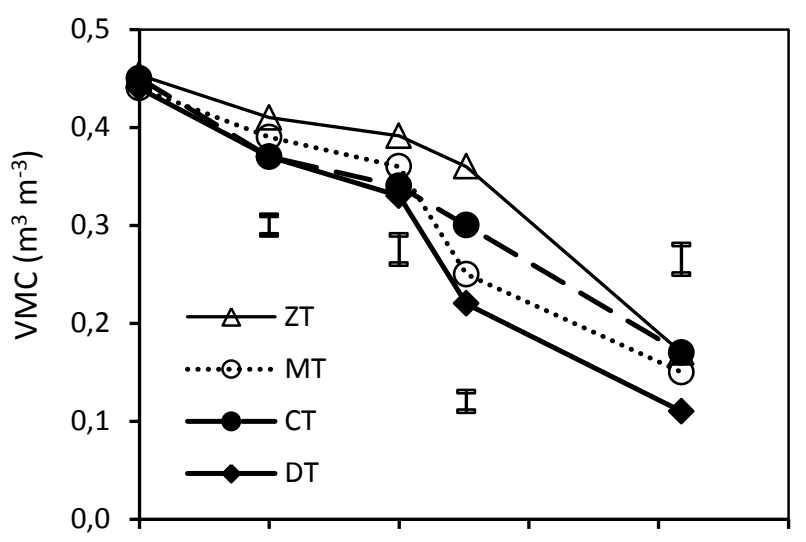

(c)

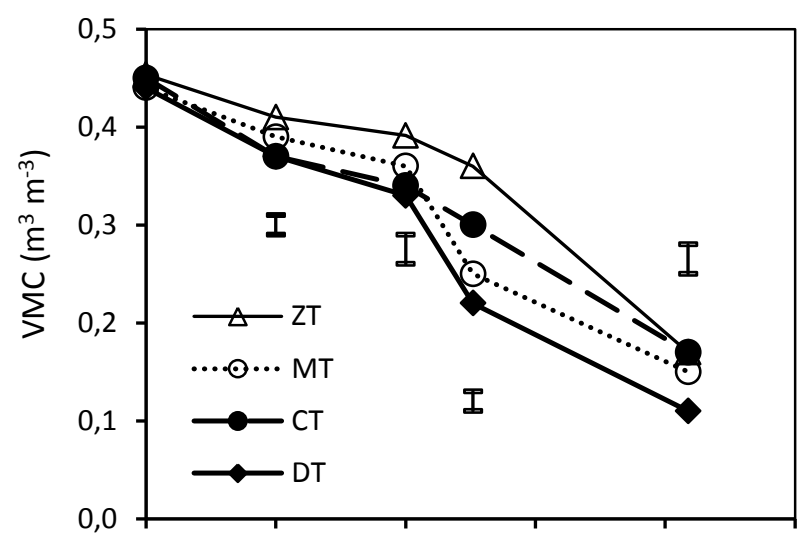

(b)

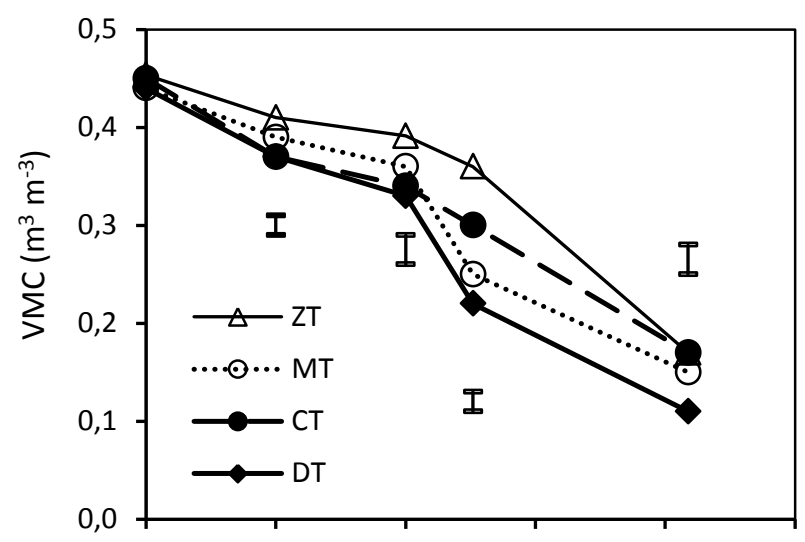

(d)

Figure 2. Effect of tillage practices on soil water retention by sampling depth: (a) $5 \mathrm{~cm}$, (b) $15 \mathrm{~cm}$, (c) $25 \mathrm{~cm}$, (d) $35 \mathrm{~cm}$. Bars indicate LSD values at a given soil water pressure when significant at $5 \%$ level. ZT: Zero tillage, MT: Minimum tillage, CT: Conventional tillage, DT: Deep tillage.

\section{Conclusion}

Based on the given conditions under which the work was carried out, the study showed the importance of zero tillage among other soil conservation practices and based on the conditions under which this work was carried out the results of the research indicated that ZT attributes can be reaped beyond upper depth. Among the tillage practices, ZT had the lowest bulk density value (1.42 and $\left.1.46 \mathrm{Mg} \mathrm{m}^{-3}\right)$ at the upper $(5 \mathrm{~cm})$ and lower $(35 \mathrm{~cm})$ depth while DT had the highest values at the corresponding depths, with 5.3 and $6.4 \%$ increment respectively. Ksat ranges in the order of DT $>\mathrm{MT}>\mathrm{CT}>\mathrm{ZT}$. The highest Ksat value in DT was due to the higher proportion of sand particles in soil under the practice. However, the hydraulic conductivity classes of the area, showed that all the soils under the tillage practices fall under same category of moderately slow hydraulic conductivity with the exception of DT practice. The VMC retained at varying soil water pressure potential was significantly different at all depths. It followed the order of ZT $>$ MT $>$ CT $>$ DT from highest to lowest. ZT also recorded the highest plant available water (PAW) with 47.3 and 15.4\%, 31.5 and $7.4 \%$ and 42.1 and $15.4 \%$ increase over MT, CT and DT practices respectively at the average depth of 5 and $35 \mathrm{~cm}$. There was no significant difference observed among the TP at the average depth of 15 and $25 \mathrm{~cm}$. Based on the findings of this study, the following recommendations were made:

1. The use of zero tillage (ZT) should be encouraged since it neither involves cost nor adverse effects on the soils.

2. The study should be extended to cover long time effects for tillage practices-TP (Zero tillage-ZT, Minimum tillage-MT, Conventional tillage-CT and Deep tillage-DT)

3. Farming practices in an upland soil that rely solely on rainfall should be based on conservation tillage practices as this study revealed their important contributions to some soil physical and hydraulic properties as well as to the plant. 


\section{References}

Afzalinia, S., Zabihi, J., 2014. Soil compaction variation during corn growing season under conservation tillage. Soil and Tillage Research 137: 1-6.

Alam, M.K., Islam, M.M., Salahin, N., Hasanuzzaman, M., 2014. Effect of tillage practices on soil properties and crop productivity in wheat-mungbean-rice cropping system under subtropical climatic conditions. The Scientific World Journal Article ID 437283.

Bai, Z.G., Dent, D.L., Lennart, O., Schaepman, M.E., 2008. Global assessment of land degradation and improvement: 1. Identification by remote sensing, Report 2008/01 (GLADA Report 5). ISRIC-World Soil Information, Wageningen, The Netherland, 70p.

Blake, G.R., Hartge, K.H., 1986. Bulk density. In: Methods of Soil Analysis Part 1 Physical and Mineralogical Methods. 2nd Edition, Klute, A., (Ed). American Society of Agronomy,-Soil Science Society of America. Madison, Wisconsin, USA. pp. 363-375.

Bronick, C.J., Lal, R., 2005. Soil structure and management: a review. Geoderma 124(1-2): 3-22.

Fuentes, J.P., Flury, M., Bezdicek, D.F., 2004. Hydraulic properties in a silt loam soil under natural prairie, conventional till, and no-till. Soil Science Society of America Journal 68(5): 1679-1688.

Gee, G.W., Bauder, J.W., 1986. Particle-size Analysis. In: Methods of Soil Analysis, Part 2, Chemical and Microbiological Properties, A.L. Page, R.H. Miller, D.R. Keeney (Eds.), 2nd Edition. Agronomy Monograph No. 9, American Society of Agronomy, Soil Science Society of America. Madison, Wisconsin, USA. pp. 383-411.

Iqbal, M., Hassan, A.U., Ali, A., Rizwanullah, M., 2005. Residual effect of tillage and farm manure on some soil physical properties and growth of wheat (Triticum aestivum L.). International Journal of Agriculture and Biology 1: 54-57.

Khan, F.U.H., Tahir, A.R., Yule, I.J., 2001. Intrinsic implication of different tillage practices on soil penetration resistance and crop growth. International Journal of Agriculture and Biology 3(1): 23-26.

Khurshid, K., Iqbal, M., Arif, M.S., Nawaz, A., 2006. Effect of tillage and mulch on soil physical properties and growth of maize. International Journal of Agriculture and Biology 8: 593-596.

Klute, A., Dirksen, C., 1986. Hydraulic conductivity and diffusivity: Laboratory methods. In: Methods of Soil Analysis Part 1 Physical and Mineralogical Methods. 2nd Edition, Klute, A., (Ed). American Society of Agronomy, Soil Science Society of America. Madison, Wisconsin, USA. pp. 687-734.

Lal, R., Stewart, B.A., 2013. Principles of sustainable soil management in agroecosystems. CRC Press. New York, USA. $552 p$.

Licht, M.A., Al-Kaisi, M., 2005. Strip-tillage effect on seedbed soil temperature and other soil physical properties. Soil and Tillage Research 80(1-2): 233-249.

Liebig, M.A., Johnson, H.A., Hanson, J.D., Frank, A.B., 2005. Soil carbon under switchgrass stands and cultivated cropland. Biomass and Bioenergy 28(4): 347-354.

López-Garrido, R., Deurer, M., Madejón, E., Murillo, J.M., Moreno, F., 2012. Tillage influence on biophysical soil properties: The example of a long-term tillage experiment under Mediterranean rainfed conditions in South Spain. Soil and Tillage Research 118: 52-60.

Mehari, A., Schultz, B., Depeweg, H., 2005. Where indigenous water management practices overcome failures of structures: The WadiLaba Spate Irrigation System in Eritrea. Irrigation and Drainage 54(1): 1-14.

Mudgal, A., Anderson, S.H., Baffaut, C., Kitchen, N.R., Sadler, E.J., 2010. Effects of long-term soil and crop management on soil hydraulic properties for claypan soils. Journal of Soil and Water Conservation 65(6): 393-403.

Muñoz, A., López-Piñeiro, A., Ramírez, M., 2007. Soil quality attributes of conservation management regimes in a semiarid region of south western Spain. Soil and Tillage Research 95(1-2): 255-265.

O’Neal, A.M., 1949. Soil characteristics significant in evaluating permeability. Soil Science 67(5): 403-409.

Page, A.L., Miller, R.H., Kuny, D.R., 1986. Methods of Soil Analysis. Part 1 Chemical and Microbiological Properties. 2nd Edition, American Society of Agronomy, Soil Science Society of America. Madison, Wisconsin, USA.

Rachman, A., Anderson, S.H., Gantzer, C.J., Alberts, E.E., 2004. Soil hydraulic properties influenced by stiff-stemmed grass hedge systems. Soil Science Society of America Journal 68(4): 1386-1393.

Ramos, M.E., Robles, A.B., Sánchez-Navarro, A., González-Rebollar, J.L., 2011. Soil responses to different management practices in rainfed orchards in semiarid environments. Soil and Tillage Research 112 (1): 85-91.

Rashidi, M., Keshavarzpour, F., 2007. Effect of different tillage methods on grain yield and yield components of maize (Zea mays L.). International Journal of Agriculture and Biology 9(2): 274-277.

Richards, L.A., 1947. Pressure-membrane apparatus. Construction and use. Agriculture and Engineering 28: $451-454$.

Salem, H.M., Valero, C., Muñoz, M.A., Rodríguez, M.G., Silver, L.L., 2015. Short-term effects of four tillage practices on soil physical properties, soil water potential, and maize yield. Geoderma 237-238: 60-70.

Seobi, T., Anderson, S.H., Udawatta, R.P., Gantzer, C.J., 2005. Influence of grass and agroforestry buffer strips on soil hydraulic properties for an Albaqualf. Soil Science Society America Journal 69(3): 893-901.

Teh, C.B.S., Jamal, T., 2006. Soil Physics Analyses. Vol. 1. University Putra Malaysia, Serdang. UPM press, Malaysia.

Zaibon, S., Anderson, S.H., Kitchen, N.R., Haruna, S.I., 2016. Hydraulic properties affected by top soil thickness in switchgrass and corn-soya-bean cropping systems. Soil Science Society America Journal 80(5): 1365-1376. 